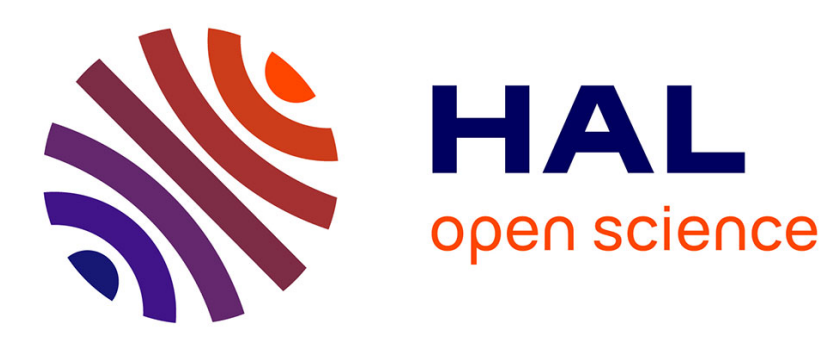

\title{
1D-2D coupling for river flow modeling
}

Pascal Finaud-Guyot, Carole Delenne, Vincent Guinot, Cécile Llovel

\section{To cite this version:}

Pascal Finaud-Guyot, Carole Delenne, Vincent Guinot, Cécile Llovel. 1D-2D coupling for river flow modeling. Comptes Rendus Mécanique, 2011, 339 (4), pp.226-234. 10.1016/j.crme.2011.02.001 . hal01196927

\section{HAL Id: hal-01196927 \\ https://hal.science/hal-01196927}

Submitted on 10 Sep 2015

HAL is a multi-disciplinary open access archive for the deposit and dissemination of scientific research documents, whether they are published or not. The documents may come from teaching and research institutions in France or abroad, or from public or private research centers.
L'archive ouverte pluridisciplinaire HAL, est destinée au dépôt et à la diffusion de documents scientifiques de niveau recherche, publiés ou non, émanant des établissements d'enseignement et de recherche français ou étrangers, des laboratoires publics ou privés. 


\title{
1D-2D coupling for river flow modeling
}

\author{
Pascal Finaud-Guyot ${ }^{\mathrm{a}}$, Carole Delenne ${ }^{\mathrm{b}}$, Vincent Guinot ${ }^{\mathrm{b}}$, Cécile Llovel $^{\mathrm{c}}$ \\ ${ }^{\mathrm{a}}$ Institut de Mécanique des Fluides et des Solides de Strasbourg (CNRS, ENGEES, INSA, UDS), 2 rue Boussingault, \\ Strasbourg, France \\ ${ }^{\mathrm{b}}$ HydroSciences Montpellier, UMR 5569 (CNRS, IRD, UM1, UM2), Université Montpellier 2, place Eugène Bataillon \\ CCMSE, 34095 Montpellier, France \\ ${ }^{\mathrm{c}}$ GEI (Ginger Environnement et Infrastructures), Montpellier, France
}

Received ${ }^{* * * * *}$; accepted after revision +++++

Presented by $£ £ £ £$

\begin{abstract}
1D-2D coupling for river flow modeling. A shallow water-based model for river-floodplain interaction (SW12D for Shallow Water 1D-2D) is presented. The main channel and floodplain are discretized using 1D and 2D elements respectively. The proposed model provides an improved description of hydraulic phenomena over existing models by (i) including lateral momentum transfer between the main channel and the floodplain, (ii) taking the $2 \mathrm{D}$ nature of the flow into account within the $1 \mathrm{D}$ elements that describe the main channel. This allows for a better description of phenomena such as head losses due to channel bends and meanders, and meander shortcuts during floods. To cite this article: P. Finaud-Guyot, C. Delenne, V. Guinot, C. Llovel, C. R. Mecanique 333 (2005).
\end{abstract}

\section{Résumé}

Couplage 1D-2D pour la modélisation des inondations fluviales. Un modèle basé sur les équations de Saint-Venant en eau peu profonde (SW12D pour Shallow Water 1D-2D) est présenté. Le lit mineur et le lit majeur sont discrétisés avec des mailles $1 D$ et $2 D$ respectivement. Le modèle proposé apporte une meilleure description (en comparaison aux modèles existants) des phénomènes hydrauliques en (i) incluant un transfert de quantité de mouvement latérale entre les lits mineur et majeur, (ii) prenant en compte la nature $2 D$ des écoulements dans les mailles $1 D$ qui représentent le lit mineur. Cela permet une meilleure description des phénomènes tels que les pertes de charge dues aux coudes et méandres et tels que les court-circuits de meandres pendant les inondations. Pour citer cet article : P. Finaud-Guyot, C. Delenne, V. Guinot, C. Llovel, C. R. Mecanique 333 (2005).

Keywords : Computational fluid mechanics; 1D-2D coupling model; Hydrodynamic modeling; Saint-Venant equations; Main-channel / floodplain interactions

Mots-clés : Mécanique des fluides numérique; Couplage 1D-2D; Modélisation hydrodynamique; Equations de Saint-Venant; Intéractions lit mineur / lit majeur 


\section{Version française abrégée}

Les approches unidimensionnelles ont prouvé leur efficacité dans la modélisation des écoulements fluviaux, tant que ceux-ci restent globalement alignés avec l'axe du cours d'eau. Lors de crues, cette approximation ne peut généralement plus être faite et des modèles à casiers ou en deux dimensions sont utilisés. Cependant, dans le premier cas, les transferts de quantité de mouvement, essentiels à la bonne représentation des phénomènes tels que les court-circuits de méandres, sont négligés. En deux dimensions, un maillage précis du lit de la rivière est nécessaire pour correctement prendre en compte la topographie. Le maillage proche du lit de la rivière doit donc également être composé de cellules de taille réduite et le pas de temps de simulation doit être réduit en conséquence pour assurer la stabilité du schéma numérique. Une approche alternative consiste à coupler les modèles $1 \mathrm{D}$ et $2 \mathrm{D}$. Cependant, les couplages existants ne sont généralement pas satisfaisants, puisque seuls les transferts de masse sont pris en compte négligeant ceux de quantité de mouvement.

Dans l'approche proposée, le couplage est réalisé en incluant le modèle 1D dans un modèle 2D : chaque maille $1 \mathrm{D}$ du lit mineur de la rivière est intégrée dans une maille $2 \mathrm{D}$ de la plaine d'inondation. Ce formalisme permet une réduction importante du nombre de mailles en comparaison d'un maillage classique 2D, et par conséquent, une réduction du temps de calcul. Les équations de Saint-Venant, établies pour chaque modèle, sont modifiées pour prendre en compte les transferts de masse et de quantité de mouvement entre les modèles. La représentation des pertes de charges liées à la sinuosité du cours d'eau ainsi que des phénomènes de court-circuit de méandres est alors possible.

Plusieurs séries de mesures expérimentales ont été réalisées et comparées aux résultats issus de la simulation numérique avec le code couplé 1D-2D (SW12D) et un code 2D classique (SW2D). Les résultats produits par SW12D sont plus en adéquation avec les mesures que ceux de SW2D. En outre, les temps de calcul sont réduits d'un facteur 1,5 à 80 selon les configurations simulées.

\section{Introduction}

One-dimensional approaches are widely used in river flow modeling due to their computational efficiency [2]. However, when the one-dimensional hypothesis are no longer valid, one-dimensional cell-based or twodimensional models have to be used. However, in the first case, the momentum transfer, that is essential to a correct representation of phenomena such as meander shortcuts, is neglected [11,3,10]. For $2 \mathrm{D}$ river flow modeling [9], a precise meshing of the river bed is required to correctly take the topography into account. The mesh must therefore be refined dramatically close to the main channel and the timestep must be reduced to ensure the numerical scheme stability. An alternative approach consists in coupling 1D and 2D models. However, existing 1D-2D models prove not to be satisfactory in the general case because only mass transfer is taken into account, while momentum transfer is often neglected.

This paper presents a new coupled 1D-2D model where momentum transfer between the main channel and the floodplain is fully considered. The proposed model is described in section 2, including hypothesis and governing equations. The numerical techniques implemented in the SW12D software are described (section 3) and computational examples are provided in section 4.

Email addresses: pascal.f inaudguyot@engees.unistra.fr (Pascal Finaud-Guyot), delenne@msem.univ-montp2.fr (Carole Delenne), guinot@msem.univ-montp2.fr (Vincent Guinot), c.llovel@gingergroupe.com (Cécile Llovel). 


\section{Model description}

\subsection{Model hypotheses}

The proposed model is based on a classical 2D model but make assumptions on the area corresponding to the main channel and its close neighborhood where a special formalism is used (see Figure 1). This formalism is based on several hypotheses. The first two concern the geometry.

(i) The flow is divided in three zones : the bottom of the main channel where flow is purely 1D (1D Zone), the floodplain where the flow is purely 2D (2D Zone) and the zone located above the main channel and the bottom of the river bank (Coupling zone). Numerically, the 2D Zone corresponds to a (classical) 2D-cell and the $1 \mathrm{D}$-cell regroups both the $1 \mathrm{D}$ Zone and the coupling zone. Each $1 \mathrm{D}$-cell is therefore fully contained in a 2D-cell. The fluxes are computed between two 1D- (or 2D-) cells. An equilibrium process is used to take the exchange between a 2D- and its contained 1D-cell into account (See section 3.1).

(ii) The bottom elevation over each $2 \mathrm{D}$-cell is constant. These two hypotheses imply that the bottom elevation is the same on each bank of the main channel.

The other hypotheses are made on the flow.

(iii) The free water surface elevation is constant over a 2D-cell and its included 1D-cell.

(iv) The longitudinal velocity $u$ is uniform over a vertical line.

(v) The transversal velocity $v$ is constant in the 2D-cell and the coupling zone. Indeed, when overflow shortcut the meanders, this hypothesis is clearly valid. In the over-flooding (or in-flooding) process, the flow goes, on both sides of the main channel, from the channel to the floodplain. Since the characteristics of the floodplain are the same on both sides of the channel, the global transfer is nil in terms of momentum because the momentum transfers at each side interface are equal with an opposite sign.

The validity of the hypothesis (iii) and (v) can be discussed. However, they are used to compute the transfer between the 1D- and its associated 2D-cell (See Section 3). In the proposed methodology, the total amount of the conserved variables (mass and momentum) on both cells is distributed at each time step between the 1D- and the 2D-cell. Any formulation that allow this distribution can a priori be used. In the present paper, the simplest formulation have been used. The aim of this article is to validate the proposed methodology. Further comparison of different formulations can be realized in a next step.

The two last hypotheses have consequences on the flow behavior:

(vi) The velocity shear between $1 \mathrm{D}$ and $2 \mathrm{D}$ flows leads to the apparition of swirls and thus to a momentum quantity transfer that can be estimated by the formulation proposed in [1] (See section $2.2)$

(vii) A vertical swirl is also created by the transversal velocity in the $1 \mathrm{D}$ zone. Due to this swirl, a head loss should be introduced. However, the phenomena has been neglected in this model.

\subsection{Governing equations}

The integral form of the governing equations is derived using a mass and momentum balance over a control volume containing both a $1 \mathrm{D}$ and a $2 \mathrm{D}$ flow [5]. These equations are then separated into one equation per domain, thus yielding an exchange term $\mathbf{T}$ :

$$
\frac{\partial \mathbf{U}}{\partial t}+\frac{\partial \mathbf{F}}{\partial x}+\frac{\partial \mathbf{G}}{\partial y}=\mathbf{S} \pm \mathbf{T}
$$




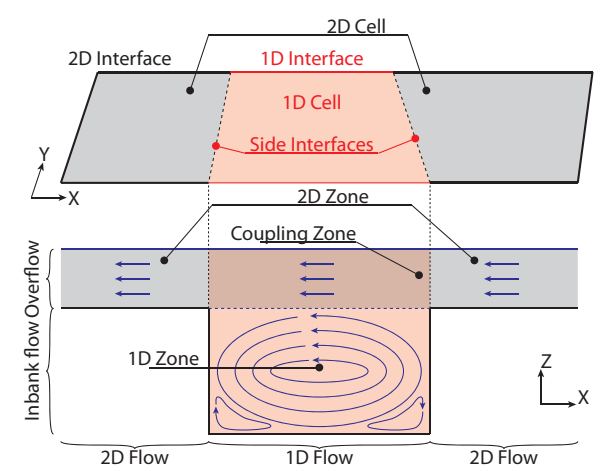

Figure 1. Assumed structure of the flow

$$
\begin{gathered}
\mathbf{U}=\left(\begin{array}{c}
\phi h \\
\phi q \\
\phi r
\end{array}\right) \quad \mathbf{S}=\left(\begin{array}{c}
0 \\
g \phi h\left(S_{0, x}-S_{f, x}\right)+\frac{1}{2} g h^{2} \frac{\partial \phi}{\partial x} \\
g \phi h\left(S_{0, y}-S_{f, y}\right)+\frac{1}{2} g h^{2} \frac{\partial \phi}{\partial y}
\end{array}\right) \\
\mathbf{F}=\left(\begin{array}{c}
\phi r \\
\phi q^{2} / h+\phi g h^{2} / 2 \\
\phi q r / h
\end{array}\right) \quad \mathbf{G}=\left(\begin{array}{c}
\phi q r / h \\
\phi r^{2} / h+\phi g h^{2} / 2
\end{array}\right)
\end{gathered}
$$

where $\mathbf{U}$ is the conserved variable, $\mathbf{F}$ and $\mathbf{G}$ are the flux functions, $\mathbf{S}$ is the source term, $g$ is the gravitational acceleration, $h$ is the water depth, $q$ (resp. $r$ ) is the unit-discharge in the $x$ (resp. $y$ ) direction, $S_{0, x}$ (resp. $S_{0, y}$ ) is the bottom slope in the $x$ (resp. $y$ ) direction, $S_{f, x}$ (resp. $S_{f, y}$ ) is the friction slope in the $x$ (resp. $y$ ) direction. The term $\phi$ stands for the porosity in $2 \mathrm{D}$ and for the channel width in 1D (as in [7], [4]).

The exchange term $\mathbf{T}$ take the transfers between the $1 \mathrm{D}$ and the $2 \mathrm{D}$ flow into account. Such exchanges stem from :

- The velocity shear between the flows generates swirls along the interfaces between both cells. The global mass exchange through the swirls is nil, however the swirls generate momentum exchange from one cell to the other. The formalism proposed in [1] is used to estimate the exchange discharge $q_{t}$ that goes simultaneously from the main channel to the floodplain and from the floodplain to the main channel :

$$
q_{t}=\psi h_{2 D}|\Delta V|
$$

where $\psi$ is a proportional coefficient, $h_{2 D}$ is the water depth along the interface, $\Delta V$ is the velocity difference between the $1 \mathrm{D}$ and the $2 \mathrm{D}$ cell. [1] has show that $\psi$ can be considered constant and equal to 0,016 .

- The mass equilibrium that insures hypothesis (iii) is respected.

- The transverse momentum equilibrium that insures hypothesis (v) is respected.

Unlike in classical 1D models, the proposed methodology uses two variables to describe momentum in the $1 \mathrm{D}$-cells as in the classical $2 \mathrm{D}$ models. The hypotheses guarantee that the transverse velocity component is nil in the $1 \mathrm{D}$-zone and equal to the transverse velocity in the $2 \mathrm{D}$ cell in the coupling zone. The flow direction change between two following 1D-cells is thus taken into account since the fluxes are computed in the referential $(\xi, \psi)$ attached to the interface (see Figure 2). Direction changes being taken into account even in the 1D equations (and therefore in the 1D model), head losses due to meanders or 

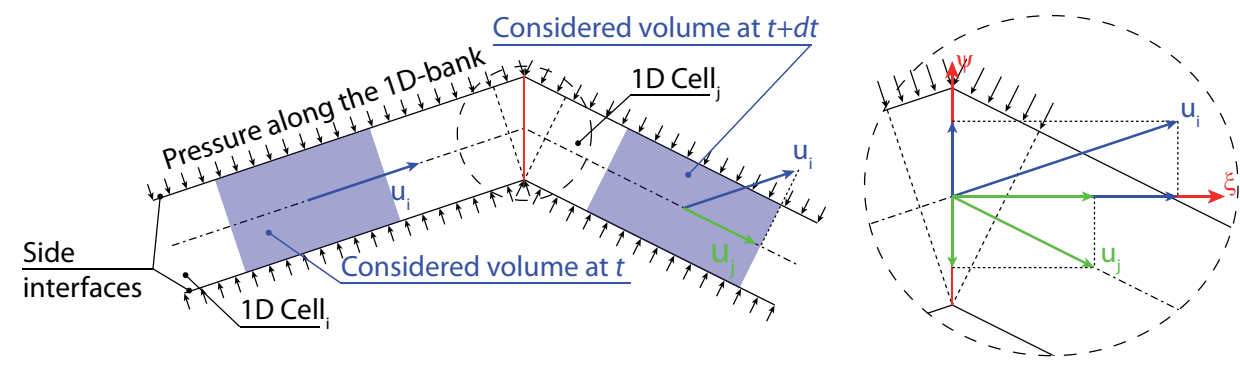

Figure 2. Velocity projections at the interface between two 1D-cells

bends are expected to be better described than in existing $1 \mathrm{D}$ models without needing to introduce head loss model.

\section{Numerical technique}

\subsection{Algorithm}

A solution algorithm has been implemented in the SW12D code using the time splitting method [6]. This approach considers the entire problem as several simpler sub-problems, each one being solved over the whole time step using the solution of the previous problem as initial condition. The source and transfer terms are split into four physical terms and two equilibrium terms:

$$
\begin{aligned}
& \frac{\partial \mathbf{U}_{1 D}}{\partial t}+\frac{\partial \mathbf{F}_{1 D}}{\partial x}+\frac{\partial \mathbf{G}_{1 D}}{\partial y}=\left[\mathbf{S}_{0,1 D}+\mathbf{S}_{p, 1 D}+\mathbf{S}_{f, 1 D}\right]+\left[\mathbf{T}_{l}+\mathbf{T}_{m}+\mathbf{T}_{t}\right] \\
& \frac{\partial \mathbf{U}_{2 D}}{\partial t}+\frac{\partial \mathbf{F}_{2 D}}{\partial x}+\frac{\partial \mathbf{G}_{2 D}}{\partial y}=\left[\mathbf{S}_{0,2 D}+\mathbf{S}_{p, 2 D}+\mathbf{S}_{f, 2 D}\right]-\left[\mathbf{T}_{l}+\mathbf{T}_{m}+\mathbf{T}_{t}\right]
\end{aligned}
$$

Equation (3) is solved using the following algorithm (see Figure 3):

- solve the conservation part with the source terms corresponding to the topography (i.e. the bottom slope $\mathbf{S}_{0}$, the pressure forces along the side-interfaces and the porosity or channel width variation $\mathbf{S}_{p}$ );

- integrate the friction terms $\mathbf{S}_{f}$;

- integrate longitudinal momentum transfer $\mathbf{T}_{l}$;

- perform mass balance $\mathbf{T}_{m}$ to respect the third hypothesis of the model;

- perform transversal momentum quantity balance $\mathbf{T}_{t}$ to enforce hypothesis (v).

After each step, an intermediate value of the conserved variable is estimated: $\mathbf{U}^{n, c}, \mathbf{U}^{n, f}, \mathbf{U}^{n, l}, \mathbf{U}^{n, m}$, $\mathbf{U}^{n, t}$. The following subsections detail each of these steps.

\subsection{Solving the conservation part of the equation}

The conservation part of equation (3) with the source terms corresponding to the topography is discretized in a finite volume framework as

$$
\mathbf{U}_{i}^{n, c}=\mathbf{U}_{i}^{n}-\frac{\Delta t}{A_{i}} \sum_{j \in N(i)}\left[\mathbf{P}_{i j} \mathbf{F}_{i j}^{n+1 / 2} L_{i j}+\left(\mathbf{S}_{i j}^{n+1 / 2}\right)_{i}\right]
$$

where the subscripts $i$ denotes the average value in cell $i$ and $i j$ denotes the interface between the cells $i$ and $j ; \Delta t$ is the computational time step, $A_{i}$ the plan view area of the cell $i, N(i)$ the set of the 


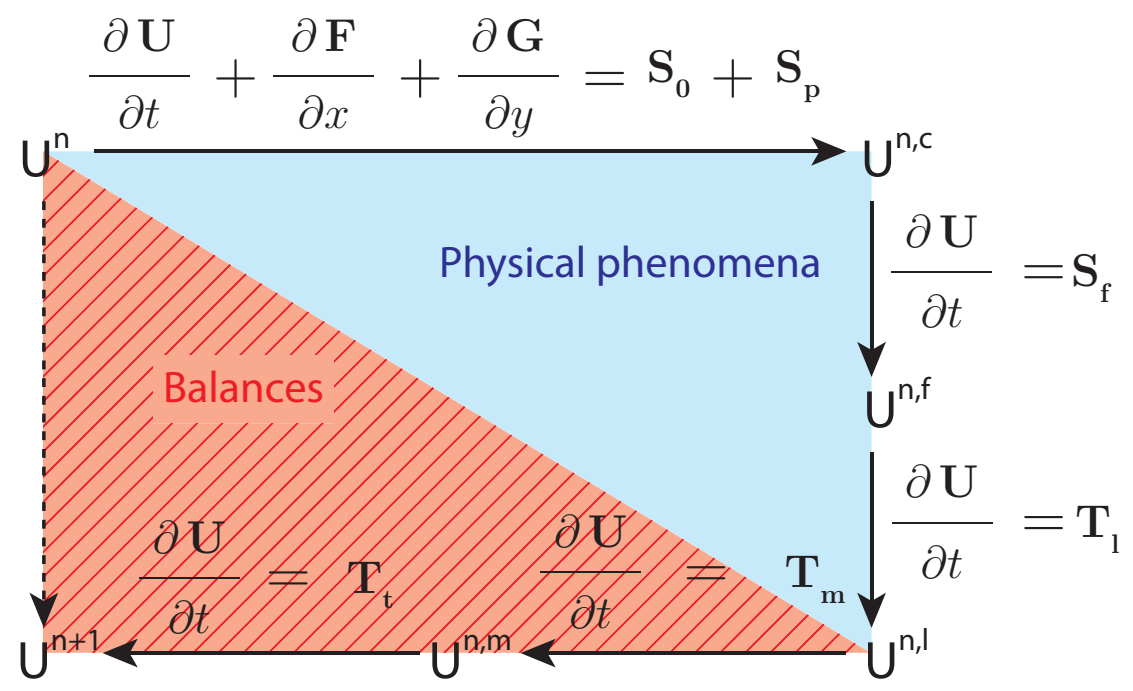

Figure 3. Algorithm of SW12D

neighboring cells of the cell $i, L_{i j}$ the width of the interface $i j, \mathbf{U}_{i}^{n}$ the average value of $\mathbf{U}$ over the cell $i$ at time level $n, \mathbf{F}_{i j}^{n+1 / 2}$ the average value of the flux at the interface $i j$ over the time interval $\left[t^{n}, t^{n+1}\right]$, $\mathbf{P}_{i j}$ the matrix that transforms the variables in the global coordinate system into the local coordinate system attached to the interface (see Figure 2) and $\mathbf{S}_{i j}^{n+1 / 2}$ the average value of the source term over the cell $i$ between the time levels $n$ and $n+1$.

The influence of the pressure forces along the bank of the main channel (i.e. the side-interfaces (See Figures 1 and 2))) is taken into account in the momentum balance. [5] has shown that the difference of the pressure forces between the left and right side-interfaces corresponds to the variation of the momentum direction in a bend.

In the proposed software SW12D, the fluxes $\mathbf{F}_{i j}^{n+1 / 2}$ and the source term corresponding to the topography $\left(\mathbf{S}_{i j}^{n+1 / 2}\right)_{i}$ between two $1 \mathrm{D}$ - (or $2 \mathrm{D}$-) cells are computed in the referential $(\xi, \psi)$ attached to the interface (see Figure 2) using the PorAS Riemann solver proposed in [4]. Since the equations involve the same number of variables (see Section 2.2) the same numerical methodology can be used for both 1D and $2 \mathrm{D}$ elements.

After this step, the free surface elevation and the transversal component of the velocity in the 1D element may not respect the model hypotheses (see Section 2.1).

\subsection{Integration of the friction term}

The friction terms are estimated by solving an ordinary differential equation in each direction of space:

$$
\frac{\mathrm{d} q}{\mathrm{~d} t}=-g \frac{\sqrt{q^{2}+r^{2}}}{K_{x}^{2} h^{2} R_{h, x}^{1 / 3}} q \quad \frac{\mathrm{d} r}{\mathrm{~d} t}=-g \frac{\sqrt{q^{2}+r^{2}}}{K_{y}^{2} h^{2} R_{h, y}^{1 / 3}} r
$$

where $K_{x}$ and $R_{h, x}$ are the Strickler friction coefficient and the hydraulic radius in the $x$ direction (resp. $K_{y}$ and $R_{h, y}$ in the $y$ direction). The hydraulic radius is approximated with the water depth except in the direction of the main-channel where the full expression of the hydraulic radius is taken into account. The explanations for such approximations are presented in [5]. 
The value of the Strickler coefficient is a parameter of the simulation. Whatever the cell is (1D or 2D), the value of this parameter should be chosen as for a classical 2D model [8]. Indeed, in the classical 1D models the Strickler coefficient, being most of the time the only one head loss driver parameter, is not only used to emulate the friction effect but also to take all the other head loss process into account (meandering, ...). Solving (5) leads to the intermediate state $\mathbf{U}^{n, f}$ with the following expressions for the unit-discharge (here in the longitudinal direction):

$$
q^{n, f}=q^{n, c} \exp \left(-g \frac{\sqrt{\left(q^{n, c}\right)^{2}+\left(r^{n, c}\right)^{2}}}{K_{x}^{2}\left(h^{n, c}\right)^{2} R_{h, x}^{1 / 3}} \Delta t\right)
$$

\subsection{Longitudinal momentum transfer}

After the friction step, the longitudinal velocity is a priori different in the 1D- and 2D-cells. Therefore, a velocity shear occurs at the interfaces between both cells (see Figure 4). Using the formulation proposed in [1], the transfered unit discharge through the interfaces can be estimated by:

$$
q_{\text {Lat }}=\psi\left|\left(u_{1 D}^{n, f}-u_{2 D}^{n, f}\right)\right| \cos \beta h_{2 D}^{n, f}
$$

where $\beta$ is the angle between the channel axis and the interface. The shear process only exchange mass between cells. Therefore, there is simultaneously a transfer from the $1 \mathrm{D}$ cell to the $2 \mathrm{D}$ one and vice versa. The unit discharge $q_{\text {Lat }}$ yields the transfered volume and the associated momentum transfer, leading to $\mathbf{U}^{n, l}$.

All the physical phenomena being taken into account, two balance steps are used to ensure that the model hypothesis are verified.

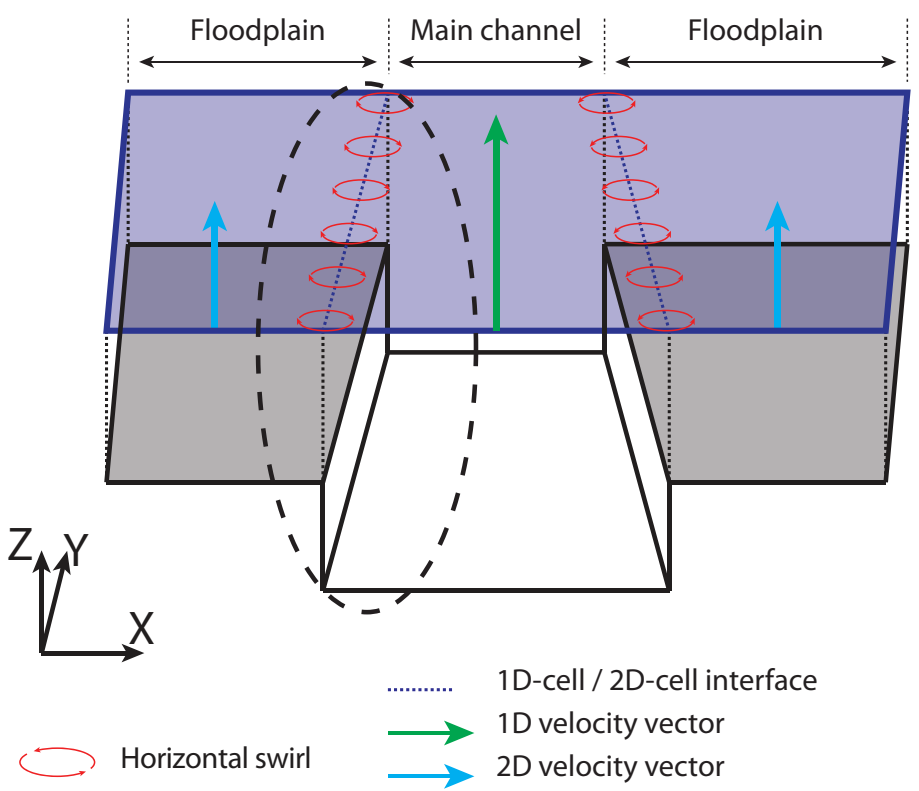

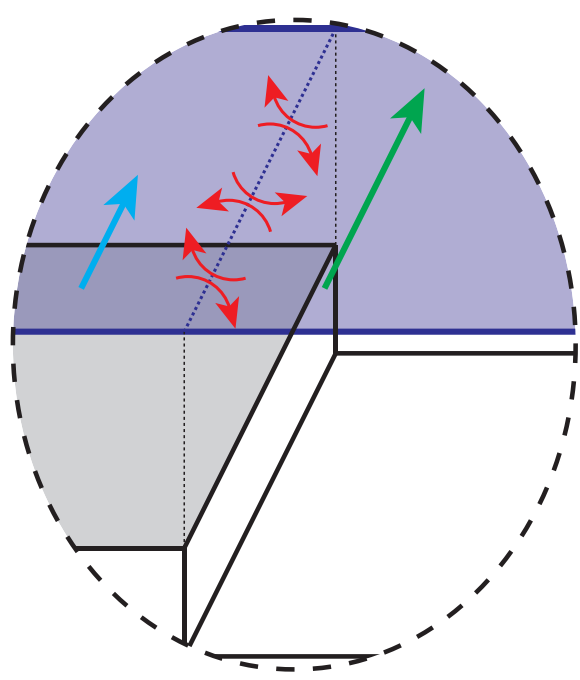

Momentum exchange due to longitudinal velocity shear

Figure 4. Longitudinal momentum transfer between 1D- and 2D-cells - Swirls due to longitudinal velocity shear. 


\subsection{Mass balance}

The mass transfer enforces hypothesis (iii) (see section 2.1). If the water volume contained in the 2D cell is smaller than the volume available in the 1D cell before overflowing, the mass and the momentum contained in the $2 \mathrm{D}$ cell are transfered in the $1 \mathrm{D}$ cell. Otherwise, the free surface elevation is modified so as to verify the hypothesis (iii):

$$
z=z_{1 D}^{n, m}=z_{2 D}^{n, m}=\frac{A_{1 D} z_{1 D}^{n, l}+A_{2 D} z_{2 D}^{n, l}}{A_{1 D}+A_{2 D}}
$$

where $A_{1 D, 2 D}$ represents the $1 \mathrm{D}$ (2D) element area and $z$ represents the free surface elevation on both $1 \mathrm{D}$ and $2 \mathrm{D}$ cells. The momentum contained in the volume transfered from one cell to the other is deduced from the upstream cell and added in the downstream one, leading to $\mathbf{U}^{n, m}$.

\subsection{Transverse momentum equilibrium}

The transverse momentum equilibrium is based on hypothesis (v) of section 2 . The transverse velocity is calculated using the following equation:

$$
v^{n+1}=\frac{A_{1 D} h_{1 D}^{n, m} v_{1 D}^{n, m}+A_{2 D} h_{2 D}^{n, m} v_{2 D}^{n, m}}{A_{1 D} h_{1 D}^{n, m}+A_{2 D} h_{2 D}^{n, m}}
$$

The longitudinal momentum contained in the volume is also transfered, leading to the solution $\mathbf{U}^{n+1}$ at time $n+1$.

\section{Computational examples}

A number of experiments on small scale model has been made to assess the capacity of SW12D in modeling different configurations (linear flow, meanders configuration...). The efficiency of the PorAS solver [4] has been tested on various numerical test cases. A comparison of the results produced by various numerical softwares (SW12D, SW2D and HEC-Ras) with the experimental data has been carried out. A comparison of SW12D and SW2D has also been performed on a real-world test case corresponding to an engineering study.

\section{1. $90^{\circ}$ bends configuration}

To estimate the ability of SW12D to model non-linear configurations, a set of experiments with $90^{\circ}$ bends has been made (Figure 5). With this geometry, two different discharges have been imposed upstream such as having an experiment with inbank flows ("Inbank configuration") and one with over-flooding ("Flood configuration"). At the downstream, the water depth has been imposed using a spillway. The experimental data of the "Inbank configuration" have been compared to the one produced by SW12D, SW2D and HECRas (Figure 6a) using a same friction coefficient (previously calibrated on various discharges in a linear configuration).

In this configuration, only SW12D matches to reproduce the experimental data. Indeed, the water depth is over- (under-) estimated respectively with SW2D and HEC-Ras. Moreover the head loss due to bends is not considered by HEC-Ras and under estimated (but well located) by SW2D (probably due to the overestimation of the water depth). In the "Flood configuration", only SW12D and SW2D have been 

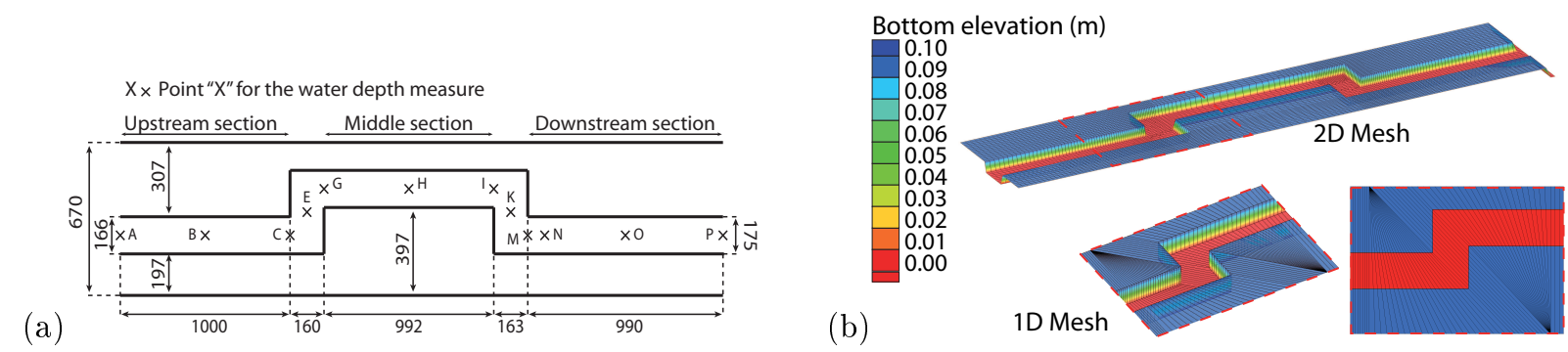

Figure 5. Meandering configuration. (a) Dimensions and measurement points (in mm), (b) Overview of the 1D and 2D meshes.
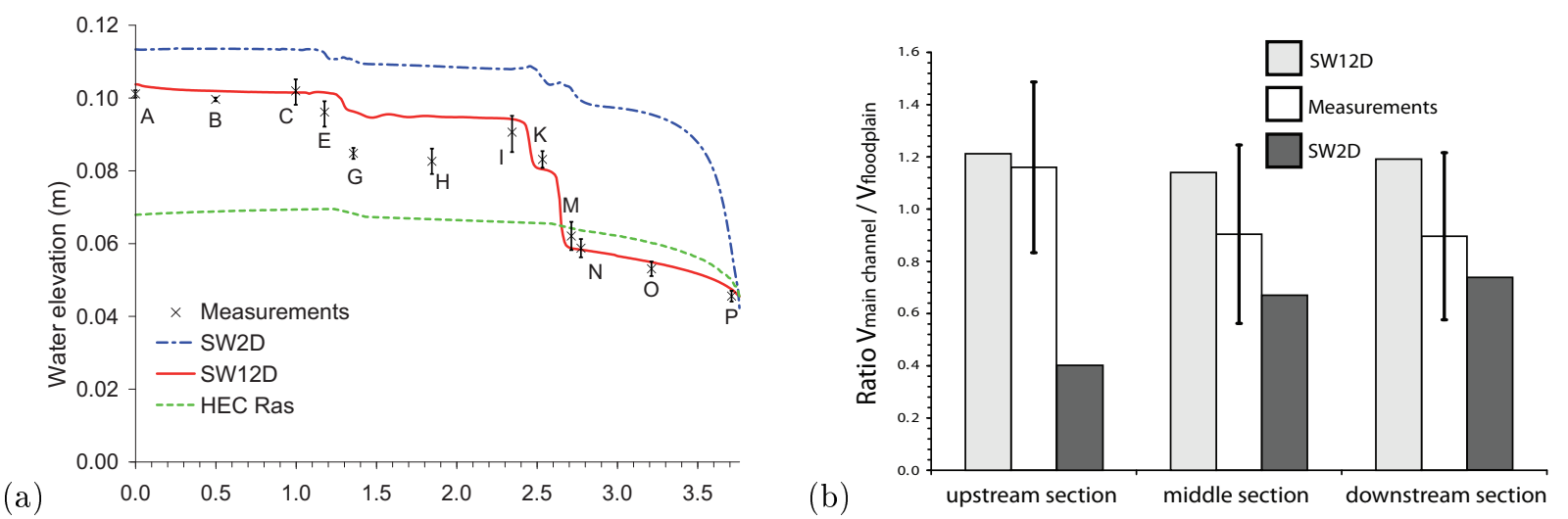

Figure 6. Comparison between numerical results and experimental values for the meandering configuration. (a) Water depth for "Inbank configuration", (b) Ratio of the velocities in the main-channel to the celerities in the floodplain for "Flood configuration"'.

used since the configuration is clearly not uni-dimensional. With both softwares, the water depth is well computed and therefore only the ratio of the velocity in the main channel to the velocity in the flood plain is represented (Figure 6b). Only SW12D correctly reproduces the ratio of the velocities.

\subsection{Real world configuration}

As SW12D should be use for real-world engineering simulations, it has been compared to SW2D on a real world configuration. Topographical and hydrological data provided by Ginger Environnement \& Infrastructures have been used. The maximal water depth and velocities produced by both softwares are presented in figure 7 and 8 .

The global hydrodynamic process is the same with both softwares and the maximal water depth are not significantly different. Nevertheless, SW2D identifies a more important transfer from the "southern" river to "middle" river. Therefore, the velocity in place of the transfer is higher with SW2D and the water depth increases at the downstream end of the "middle" river. The differences between the results are due to the imprecision of the modeling process. From the data available, it is impossible to state whether SW2D or SW12D is the most accurate and both produce acceptable results. 


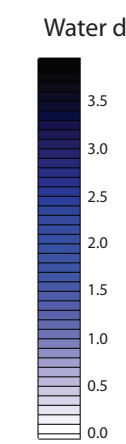

(a)

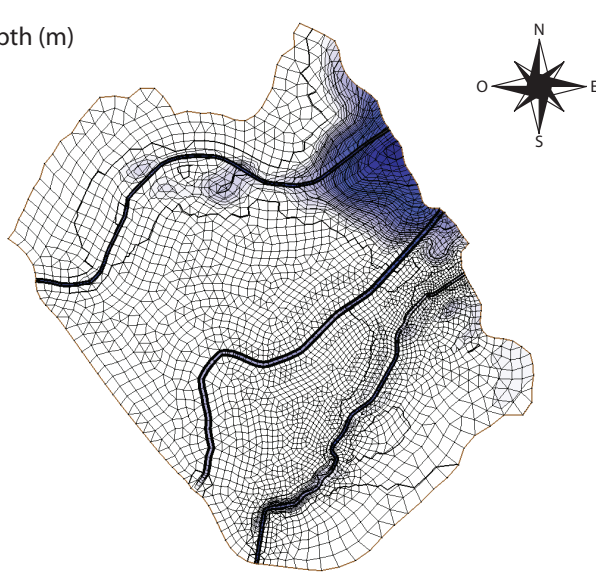

(b)

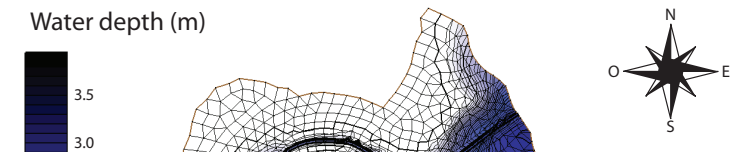

Figure 7. Comparison of the maximal water depth for the real-world simulation. (a) SW12D , (b) SW2D

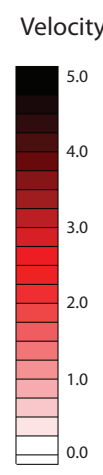

(a)

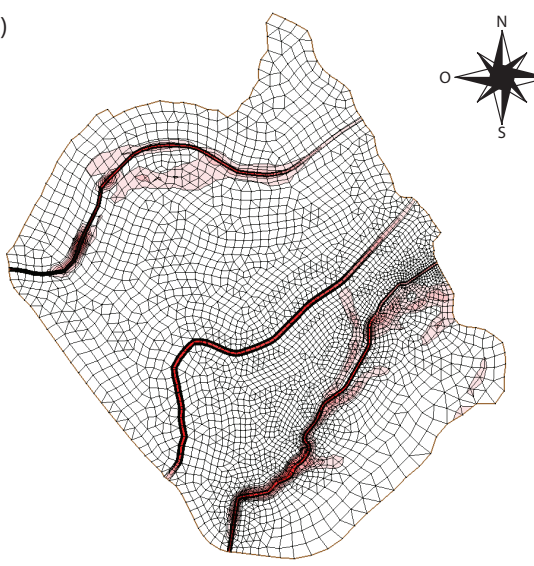

Velocity $(\mathrm{m} / \mathrm{s})$

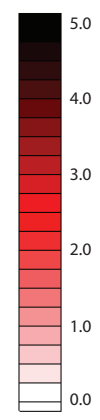

(b)

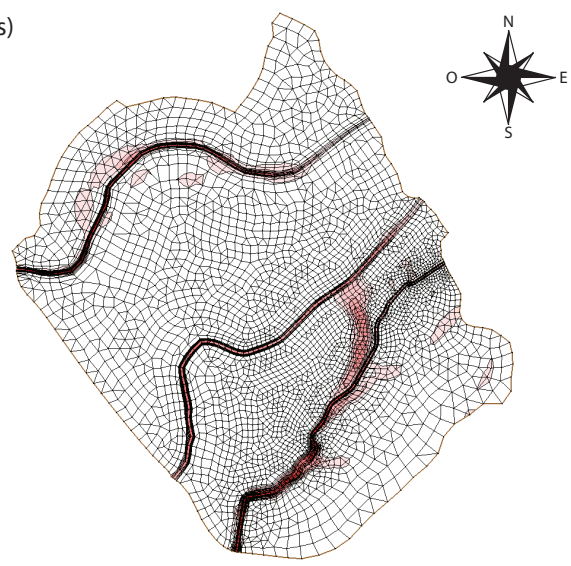

Figure 8. Comparison of the maximal velocities for the real-world simulation. (a) SW12D , (b) SW2D.

\begin{tabular}{lccc} 
Simulation & \multicolumn{2}{c}{ Time process (s) } & Time reduction \\
& SW2D & SW12D & factor \\
\hline Meandering without overbank flow & 1967 & 38 & 52 \\
Meandering with overbank flow & 2671 & 33 & 81 \\
Real-world test case & 3418 & 212 & 16 \\
\hline
\end{tabular}

Table 1

Computational time in s

\subsection{Computational times}

For all the different configurations, the computational times using SW12D are smaller to the one using SW2D (See Table 4.3). For the 1D configurations, the computational time is equal using SW12D or HEC-Ras. 
It appears that SW12D requires an equivalent computational time to a $1 \mathrm{D}$ software and is at least 16 times (and up to 81 times) faster than SW2D.

\section{Conclusion}

The 1D-2D coupling methodology presented in this paper allows both mass and momentum transfer between the 1D and the 2D models to be accounted for. This is a significant improvement compared to a classical 1D-2D software. Moreover, the results obtained with SW12D have, at least, the same accuracy as the results from SW2D, a classical 2D software. For all the simulations, SW12D appears to be faster, reducing the processing time up to 81 times. Ongoing research focuses on (i) validating this software under different configurations, (ii) comparing SW12D to other 1D-2D and 2D software packages and (iii) extending the methodology to non-rectangular 1D channels and taking confluences into account. At longer term, ongoing research will focuses on developing a methodology that allow to have different configurations of the topography and the flow on each banks of the main channel (i.e. by linking one $1 \mathrm{D}$-cell with two 2D-cells (one on each side)).

\section{Acknowledgments}

This research was carried out during a Ph. D. Thesis funded by GEI (Ginger Environnement et Infrastructures), a GINGER Group company during a CIFRE grant (ANRT contract n $2006 / 838$ ).

\section{References}

[1] D. Bousmar. Flow modelling in compound channels. PhD thesis, Université Catholique de Louvain, 2002.

[2] J.A. Cunge, F.M. Jr. Holly, A.Verwey. Practical aspects of computational river hydraulics. Pitman publishing Ltd. London, 1980.

[3] DHI. Mike 11, A Modelling System for Rivers and Channels - Reference Manual, 2004.

[4] P. Finaud-Guyot, C. Delenne, J. Lhomme, V. Guinot, and C. Llovel. An approximate-state Riemann solver for the two-dimensional shallow water equations with porosity. International Journal for Numerical Methods in Fluids, 2009. A paraître.

[5] P. Finaud-Guyot. Macroscopic flood modelling: Taking into account directional flows and main channel - floodplain transfer. PhD thesis, Université Montpellier 2, 2009. A paraître (In French)

[6] V. Guinot. Godunov-type shcemes, An introduction for engineers. Elsevier, 2003.

[7] V. Guinot and S. Soares-Frazão. Flux and source term discretization in two-dimensional shallow water models with porosity on unstructured grids. International Journal for Numerical Methods in Fluids, 50:309-345, 2006.

[8] V. Guinot and B. Cappelaere. Sensitivity analysis of 2D steady-state shallow water flow - Application to free surface flow model calibration. Advances in Water Resources, 32:540-560, 2009.

[9] J.M. Hervouët. Hydrodynamique des écoulements à surface libre - Modélisation numérique avec la méthode des éléments finis. Ponts et Chaussées (Presses), 2003 (In French).

[10] HR Wallingford. Isis Flow - User Manual, 1999.

[11] US Army Corps of Engineers, Hydrologic Engineering Center. HEC-RAS, River Analysis System - Hydraulic Reference Manual, November 2002. 